\title{
TRANSLATION OF ENGLISH SLANG IN ADVERTISEMENTS
}

\section{ПЕРЕКЛАД РЕКЛАМНОГО АНГЛОМОВНОГО СЛЕНГУ}

\section{Kateryna Shevchyk ${ }^{1}$}

DOI: https://doi.org/10.30525/978-9934-26-051-3-9

Abstract. In the modern world, in the epoch of growth of information technologies, an advertisement is one of the most popular varieties of mass communication that rapidly develops. The growth of advertisement substantially influences on lexical composition of language, creates in a language new concepts and expressions, in particular slang and jargon. Native speakers begin to use such vocabulary in everyday life. Especially modern English has such phenomenon, because it is used all over the world.

Nowadays, an advertisement performs the function of public ideas formation. Influencing on people, an advertisement creates consumer philosophy and ideology.

One of the most sensible to the advertisement categories of people is youth, because they are in the process of active socialization. Exactly an advertisement is mostly aimed at young consumers, that is why it becomes more widely spread and such products need specific language means of influence. Advertisement makers try to overcome psychological distance between an advertisement and audience, so they use of extralinguistic language units, elements of slang or to create new words.

Topicality of this work is defined by the fact that a slang is an integral part of English, and the latest research of slang is of great importance. A slang is one of the most actual and ambiguous problems of modern lexicology. In the world where new slang units appear every day, updating of theoretical and practical knowledge of slang and its functions is very important for modern lexicology. In addition, the deeper analysis of advertisement reports with a slang must be done.

\footnotetext{
${ }^{1}$ Candidate of Philological Science, Associate Professor, Department of Translation and Linguistic Training of Foreigners, Oles Honchar Dnipro National University, Ukraine

(C) Kateryna Shevchyk
} 
A scientific novelty of work is that theoretical knowledge in relation to a slang and advertisement in the conditions of modern development of information technologies are incorporated and generalized; opinions of scientists are analyzed in relation to functioning of slang in an advertisement.

The aim of the article is to study features of slang functioning in modern English-language advertisements and analysis of basic methods of translating of such advertisement texts.

The achievement of these aims needs solution of the following tasks:

1) to interpret a concept «slang» and «jargon» and define, what a slang differs from jargon in the context of the newest researches;

2) to present the basic methods of forming of slang in modern English;

3 ) to describe the general views of slang and identify their specifics;

4) to interpret a concept «advertisement» and describe the stylistic features of advertisement text;

5) to describe the features of slang use in advertisement texts;

6) to explain functioning of slang in an advertisement on the example of advertisement slogans and texts;

7) to define the specific features of English-Ukrainian translation of advertisements.

The subject of research is an analysis of slang features in modern English and Ukrainian languages in advertisement texts.

\section{1. Вступ}

У сучасному світі, в епоху швидкого розвитку інформаційних технологій, реклама є одним із найпопулярніших різновидів масової комунікації, що активно розвивається. Швидкий розвиток реклами суттєво впливає на лексичний склад мови, наповнює мову новими поняттями та виразами, зокрема такими, як сленг і жаргон. Носії мови починають вживати таку лексику у повсякденному житті. Особливо схильна до таких запозичень англійська мова, адже іiі використовують люди в усьому світі.

Реклама сьогодні виконує функцію формування суспільної думки. Впливаючи на аудиторію, реклама робить свій внесок у створення споживчої філософії та ідеології.

Однією з найчутливіших до реклами категорій є молодь, адже вона перебуває в процесі активної соціалізації. Саме реклама здебільшого 
націлена на молодих споживачів, тому її стає все більше - і така продукція потребує специфічних мовних засобів впливу. Рекламісти, для долання психологічної відстані між рекламою та аудиторією прагнуть наблизитися до молоді, вдаючись до використання позалітературних мовних одиниць, елементів сленгу або до створення нових слів та конструкцій за їх зразками.

Сфери і закони функціонування сленгу в сучасній мові все частіше стають об'єктом наукового аналізу. Проблему вживання сленгу вивчали I. Н. Ганжа, Я. Ж. Тардіф, Т. Г. Нікітіна, О. В. Уздинська, Л. О. Ставицька, О. М. Береговська, Л. А. Кудрявцева, І. В. Арнольд, С. Б. Флекснер, К. Ебл, Е. Партрідж.

Актуальність цієї роботи зумовлена тим, що сленг є невід’ємною частиною англійської мови, а наявні дослідження сленгу не є новітніми. Сленг є одною з найактуальніших та неоднозначних проблем сучасної лексикології. У світі, в якому нові сленгові одиниці виникають мало не щодня, оновлення теоретичних та практичних знань про сленг, його функції та особливості є важливим для сучасної лексикології. Крім того, потрібно надати глибший аналіз рекламних повідомлень, у яких використано сленг або жаргон.

Наукова новизна роботи в тому, що у ній об'єднано та узагальнено наявні теоретичні знання щодо сленгу та реклами в умовах сучасного буму інформаційних технологій; окреслено та проаналізовано думки науковців щодо функціонування сленгу у рекламі.

Метою дослідження $\epsilon$ вивчення особливостей функціонування сленгізмів і жаргонізмів у сучасних англомовних рекламних текстах та аналіз основних способів перекладу таких рекламних текстів.

Досягнення поставленої мети передбачає розв'язання таких завдань:

1) витлумачити поняття «сленг» і «жартон» та визначити, чим сленг різниться від жаргону в контексті новітніх досліджень;

2) представити основні способи формування сленгу в сучасній англійській мові;

3) охарактеризувати загальні види сленгу та вказати їхню специфіку;

4) утлумачити поняття «реклама» та описати стилістичні особливості рекламного тексту;

5) охарактеризувати особливості використання сленгу в рекламних текстах; 
6) пояснити функціонування сленгу в рекламі на прикладі рекламних слоганів і текстів;

7) визначити специфічні особливості англо-українського перекладу рекламного сленгу.

Методи дослідження. Під час написання статті використано метод порівняння, узагальнення, аналізу, синтезу, інтерпретації та зіставний метод.

Предметом дослідження $є$ аналіз особливостей сленгізмів у сучасних англомовних та україномовних рекламних текстах.

Об'єктом дослідження $є$ сленгові одиниці англійської та української мов.

Методологійною основою дослідження послуговують принципи системності (багатовекторна репрезентація мовної системи та їі підсистем), дослідження Ш. Баллі, І. О. Бодуена де Куртене, А. Мейе, О. О. Потебні, Ф. де Соссюра, детермінізму (обумовленість стандартних та субстандартних елементів мови) (праці В. М. Жирмунського, В. Г. Костомарова, Д. С.Ліхачова, Є. Д. Поліванова).

\section{2. Поняття сленг та жаргон у науковій літературі}

У науковій літературі сьогодні немає однозначного визначення терміну «слент». Лінгвістичний енциклопедичний словник тлумачить це поняття як аналогічне жаргону, а також як сукупність жаргонізмів, які складають шар розмовної лексики, що означає грубувато-фамільярне, подеколи гумористичне ставлення до предмета мовлення [17].

У словнику лінгвістичних термінів сленг кваліфікують як «слова, які часто порушують норми стандартної мови. Це дуже виразні, іронічні слова, що служать для того, аби називати предмети, про які говорять в повсякденному житті» [1, с. 301].

Вважаємо, що важливо чітко сформулювати різницю між сленгом та жаргоном, аби надалі можна було відрізняти ці два феномени один від одного.

Отже, жаргон (з франц. jargon - балаканина) - особливості мовлення певної соціальної, вікової або професійної групи людей, пов'язаних тривалим перебуванням разом або певною спільністю інтересів. Від літературної мови жаргон відрізняється специфічною лексикою та вимовою, хоч і не має власної фонетичної та граматичної системи. 
Єдиний різновид жаргону, який має переважно письмову форму в той час, як інші жаргони представлені в основному усними формами, наприклад, комп'ютерний.

Жаргонізми - слова або вислови, уживані представниками певної соціальної або професійної групи. Як вже зазначалося раніше, поняття жаргону і сленгу здебільшого вживають як синоніми. Це пояснюється передусім тим, що таке змішування часом відбувається і в мовознавчій літературі.

Л. О. Ставицька наголошує на потребі диференціації сленгу й жаргону: «Поняття «жаргон» історично вказує на обмеженість групи його носіїв, а також на вузькість семантичного поля лексичних одиниць. Мовне середовище спілкування великої кількості людей, яке відрізняється від мовної норми, отримало найменування «сленг» [14].

Сленг (із норв. sleng - лаятися) - інтержаргонне явище; особливості мовлення чималих верств носіїв мови, пов'язаних не лише груповою, корпоративною спільністю, а й просторовою, наближаючись до просторіччя.

Як зазначено в Енциклопедії «Украӥнська мова», «сленгові властиво запозичувати одиниці арго і жаргону, переосмислюючи та розширюючи їхні значення. За структурою сленг поділяється на загальний і спеціальний (професійний жаргон та мову певних соціальних прошарків). Загальний сленг - відносно стійкий, досить поширений і загальнозрозумілий шар лексики та фразеології в середовищі живого розмовного мовлення...» [12].

Л. О. Ставицька зауважує, що жаргон - це соціально маркована лексика. У професії журналіста, водія чи науковця є нормативний ряд, який використовується для офіційного спілкування, а є знижений, фамільярний з модусом жаргону як засобу сміхового олюднення світу. Жаргон є розмовною лексикою, що побутує в певному корпоративному середовищі. Спілкуючись одне з одним, ми виробляємо особливий субкод, який об'єднує нас, відокремлює від інших і є розпізнавальним знаком: ми - свої, ми належимо до одного середовища» [14].

На думку П. М. Грабового, «одним із чинників, що ускладнюють диференціальне розмежування термінів «арго», «жартон», «сленг», $€$ те, що і в самих мовах, із яких терміни були запозичені, відбувається уточнення та розширення їхнього значення. Можна припустити, що 3 
плином часу відбудеться така зміна конотативного значення термінів «жартон», «слент» та «арго», пов’язана $з$ диференційним розмежуванням означених термінів. У сучасній україністиці більшість дослідників вказують на повну взаємовідповідність термінів «сленг» $i$ «жарІон», відсутність негативної конотації терміну «жаргон» [6].

Професійні жаргонізми - образно-експресивні слова та вислови, що мають нейтральні відповідники і побутують переважно в усному мовленні людей певної професії чи роду занять, об'єднаних спільними інтересами, належністю до певного соціально-професійного соціуму.

За допомогою жаргону люди ототожнюють себе 3 певними соціальними угрупованнями, починаючи зі школярів і студентів, молодих бізнесменів і хакерів та закінчуючи злочинцями, пияками та наркоманами.

Дослідники висловлюють різне ставлення до сленгу й жаргону. Одні уналежнюють їх до паразитарних видів лексики, які засмічують мовлення. Інші наголошують на тому, що властиві сленгові та жаргонові образність та емоційність збагачують мову експресивними засобами, що є позитивною тенденцією для розвитку мови. О. Д. Пономарів упевнений, що «психологічною основою появи жаргонізмів $€$ прагнення носіїв мови бути дотепними, це результат властивого людям бажання порозважатися. Жартон - суспільна забава. Мовна гра, підпорядкована бажанню підсилити експресію» [11]. К. Г. Городенська стверджує: «у певних групах носіїв мови є бажання бути дотепними, прагнення вразити співрозмовників свіжістю та яскравістю висловлення, виявити зневагу або байдужість до предмета висловлення, уникнути звичних, затертих слів і виразів» [5].

О. С. Шалова називає сленг «мовною грою, що допомагає особистості заявити про себе у власному мікросоціумі та водночас відокремитись від решти суспільства» [15]. Ю. В. Шевельов відзначає: «...міський сленг належить до найактивніших прошарків сучасних мов... міський сленг націлений у майбуття мови».

Чимало дослідників (К. Ебл, С. Е. Добланович і ін.) переконані, що сленг є ознакою життя і розвитку мови. Згідно К. Ебл, «сленг - розмовні слова та фрази, що постійно змінюються і які мовці вживають для встановлення або акцентуації соціальної приналежності до тієї чи тієї групи» $[18$, с. 10$]$. 
С. Е. Добланович стверджує, що «сленг - це ознака життя і поступового, послідовного розвитку мови, ознака постійної зміни його ладу, переважно лексичного» [7].

Цікавими, на наше переконання, є молодіжні жаргони, характерні для мовлення осіб до 35 років. Під терміном молодіжний жаргон П. М. Грабовий пропонує розуміти особливий мовний субкод, що характеризується використанням ненормативних, зазвичай стилістично знижених, лексико-фразеологічних одиниць, які виконують оцінну, евфемістичну та номінативну функцію і використовуються в невимушеному спілкуванні молоддю [6].

Загальномолодіжний жаргон - та частина молодіжного жаргону, яка номінує максимально актуальні для молодих людей реалії, його розуміють і вживають всі соціально-вікові групи молоді. Загальномолодіжний жаргон характеризує мову певного покоління і $є$ за своєю природою динамічною, підвладною швидкоплинній моді, лексичною системою. Локальних видів молодіжного жаргону нараховують близько сорока.

Наведемо приклади жаргонізмів серед таких груп молоді:

1) школярі - гальорка (остання парта), домашка або дезе (домашнє завдання);

2) студенти - абітура (абітурієнт), фак (факультет), стипуха, Баба Cтепа (стипендія);

3) комп'ютерники - юзер (користувач персонального комп'ютера), клава (клавіатура), мило (e-mail), забанити (заборонити доступ до чогось), зависнути (не відповідати на команди), кіллер фіча (від англ. killer feature - особливість або характеристика програмного продукту);

4) солдати - сундук (мічман), дідівщина (нестатутні стосунки в армії), дід (солдат, якому до кінця служби лишилося менше, ніж півроку);

5) гравці - шутер (від англ. shoot - стріляти, гра-стрілялка), квакати (грати в комп'ютерну гру Quake), думер (особа, яка грає в гру DOOM), павнити (перемагати в грі з великим відривом від сіперників)

6) рольовики - павільйонка (рольова гра в приміщенні), толкієноїд (особа, яка захоплюється творами Толкієна).

Серед жаргонізмів є чимало багатозначних слів:

мило - електронна пошта; мильна опера (про телесеріали);

попсовик - людина, щзо слухає чи виконує музику в стилі поп; людина, щзо нічого не розуміє в житті. 
Словник містить широке та вузьке значення до терміну «сленг». В широкому значенні сленг - це розмовний варіант професійного мовлення, синонімом якого є жаргон. Натомість у вузькому значенні сленг - це «жаргонні слова або вислови, характерні для мовлення людей певних професій або соціальних прошарків, які, проникаючи в літературну мову, набувають помітного емоційно-експресивного забарвлення» [13].

Отже, із зазначеного постає, що ці терміни є близькими та майже синонімічними. Серед мовознавців поширена така думка: всі ці три терміни (жартон, слент і арго) - це синоніми, оскільки вони називають ненормативне мовлення соціальних чи професійних груп. Тобто це їх широке, інакше кажучи, «нетермінологічне» значення.

Найдоречніший, на нашу думку, критерій для розрізнення лексики, яку позначають ці два терміни (сленг та жаргон) належить відомій українській дослідниці Л. О. Ставицькій, з «пера» якої вийшли перші в українській мові словники ненормативної лексики, зокрема: «Короткий словник жаргонної лексики української мови» (2003), «Український жаргон. Словник» (2005), «Українська мова без табу. Словник нецензурної лексики та її відповідників» (2008).

Отже, критерієм розрізнення всіх трьох груп неформальної (чи ненормативної) лексики є ступінь її відкритості [10].

Схарактеризуємо у такий спосіб:

1) сленг - це найвідкритіша лексична підсистема;

2) жаргон - це напіввідкрита лексична підсистема;

3) арго - це найзакритіша лексична підсистема.

Отже, порівняймо терміни «сленг» і «жартон».

Обидва ці терміни можуть вживатись, якщо вони позначають відповідну лексику за ступенем відкритості. Тобто якщо це слова певної молодіжної субкультури чи професійної групи, які є маловідомими широкому загалу, то можна 3 повним правом їх назвати молодіжним жаргоном.

У разі, коли такі специфічні «молодіжні» слова є загальновідомими, то йдеться, звичайно, про молодіжний сленг.

Наприклад, розуміти позначається в молодіжному середовищі кількома сленгізмами: в '̈̈хати, вкурити, втягнути.

Те ж саме можна говорити й, наприклад, про комп'ютерний сленг та жаргон, спортивний сленг та жаргон та ін. 
3 упевненістю можемо сказати, що термін «молодіжний слент» вживають набагато частіше, ніж термін «молодіжний жартон».

Отже, для жаргону характерна жорсткіша соціально-групова спрямованість. Частина такої лексики має стосунок до особливої термінології, доступної для розуміння лише деяких людей. Відмінність жаргону від сленгу полягає в тому, що жаргонізми виникають в конкретній групі, зазвичай в зв'язку з якими-небудь нововведеннями, розробками. Сленг ж, крім власного словотворення, нерідко черпає свій матеріал 3 жаргону різних груп суспільства, відбираючи найуживаніші та найпопулярніші. На підставі цього сленг подеколи називають загальним жаргоном.

Потрібно відзначити, що особливі слова, проникаючи зі сфери спілкування тієї чи тієї групи людей в загальновживану мову, зазвичай дещо змінюють своє початкове значення. Наприклад, шісткою в певних колах називають того, хто прислуговує злодіям. У звичайній мові таким словом можуть презирливо назвати будь-яку людину, важливість та роль якої незначна.

Сленг, через свою легкість і рухливість, переважно асоціюють 3 мовленням молоді, але чималу популярність він має і в людей старшого віку. Взагалі, в порівнянні з жаргоном, сленг відрізняється більшою масовістю. Його соціальна обмеженість хоч і наявна, проте є нечіткою. Носіями одних і тих же сленгізмів можуть бути люди різних професій і освітнього статусу, що не мають кримінального минулого і $є$ цілком благопристойними і інтелігентними.

Таким чином, аналіз підходів до визначення поняття «сленг» в науковій літературі дає можливість виробити робоче визначення цього поняття, яким послуговуватимемося в цьому дослідженні. У межах нашої розвідки під сленгом розуміємо набір особливих емоційно забарвлених слів, які не прийняті в літературній мові.

\section{3. Класифікація сленгової лексики}

Через динамічний розвиток мови за період життя одного покоління його лексичний запас зазнає серйозних змін. Ці зміни характеризуються не лише збільшенням або зменшенням обсягу словникового запасу, але й кардинальними змінами у багатокомпонентних словосполученнях та виразах. Не існує однозначного ставлення до питання використання сленгу в різних стилях мови. 
Для носіїв англійської мови сленгізми - це допоміжні засоби задля вираження почуттів та думок, які зрозумілі більшості носіїв англійської мови. Основною рисою сленгової одиниці є те, що вона не має співвідношення з будь-якою певною соціальною групою і не є індикатором певної субкультури, на відміну від арготизмів, жаргонізмів або професіоналізмів.

Для молодіжного сленгу характерна велика кількість особливостей і відмінностей від інших наявних сленгів, таких як професійний (сленг лікарів, юристів, бухгалтерів та ін.), соціальних верств населення (сленг злочинного світу, бомжів). До них, насамперед, можна уналежити швидку динаміку молодіжного сленгу, яку можна пояснити постійним оновленням та поповненням лексичного запасу сленгу. Сленг - це лише один з рівнів мови. Будь-яка жива вербальна мова $\epsilon$ багаторівневим утворенням.

Відмінною рисою сленгу є підвищена експресивність, номінування реалій та понять, що виникають у сучасній розмовній мові, а також вирізняють ті лексичні одиниці, що досі не мають відповідників у літературній мові. Швидкоплинність та нестійкість - це істотна особливість сленгової мови, тому якщо певну лексичну одиницю не використовують досить активно, то на зміну їй виникає нова лексична одиниця, яка $\epsilon$ емоційно забарвленішою. Виходячи з багатьох досліджень сучасний сленг позиціонують як один з рівнів англійської мови.

Сучасний молодіжний сленг доволі точно номінує різноманітні реалії, через те виникає велика кількість синонімів та антонімів.

Ця лексика має переважно негативну емоційно-експресивну оцінку (несхвалення, зневага, презирство, приниження). Основне значення цієї лексики - бути засобом емоційно-експресивного вираження, своєрідним вираженням «протесту» проти звичного слововживання. Молодіжному сленгу властиві динамічність, мовна гра, нечіткість.

Важливим, на наше переконання, є визначення причини використання сленгу в мові. Наприклад, у своїй роботі «Slang Today and Yesterday» Е. Партрідж виділяє такі причини вживання сленгу [19]:

1) для розваги;

2) для гумору;

3) для підкреслення своєї індивідуальності;

4) аби надати мови більшої яскравості; 
5) для того, щоб здивувати тих, хто оточує;

6) для збагачення свого словникового запасу;

7) для створення дружньої атмосфери;

8) для демонстрації належності до будь-якої соціальної групи;

9) для прийняття у ролі «свого» в компанії;

10) для зменшення або перебільшення чого-небудь;

11) для того, аби не використовувати кліше чи багатослів'я.

Соціопсихологічна мотивація, що зумовлює використання у мовленні сленгових лексичних одиниць, перебуває у площині сміхової, неофіційної культури. Сміхова культура відповідає рівню довербального, інтелекту, дій та образів. Первісне світовідчуття, відбите у мові, відзначається емоційністю, перевагою конкретного над абстрактним, різким протиставленням «свого» та «чужсого» тощо.

Переважно таке світовідчуття виявляє себе опосередковано, що підтверджують, наприклад, сленгові номінації на позначення особи за належністю до певної раси: людина, що відрізняється кольором шкіри, очей, вимовою тощо, кваліфікується як чужа, ворожа, що й відображається у відповідних сленгових лексичних одиницях, наприклад, укр. хачик (зневажл. вірменин); лумумба (представник негроїдної раси); англ. God forbid (зневажл., образл. Сврей), jungle bunny (зневажл., образл. представник негроїдної раси, переважно з країн, що знаходяться в тропіках) тощо.

Аналіз українських та англійських сленгових лексичних одиниць, дав змогу визначити такі лексико-семантичні типи назв:

- живого: людини, тварини;

- продуктів господарської, технічної та соціальної діяльності людини; - абстрактних понять: явищ, ситуацій, подій.

Зазначені лексико-семантичні угруповання є розгалуженою та багаторівневою організацією груп, як назви живого: назви тіла, організму, їх частин, продуктів життєдіяльності, наприклад: укр. бодун [13] (алкогольний абстинентний синдром); англ. the jim-jams [20] (запаморочення, викликане надмірним вживанням алкоголю);

- продуктів господарської, технічної і соціальної діяльності людини: англ. mivvy (жінка-професіонал у своїй сфері);

- матеріальних продуктів діяльності людини: укр. шиотки (одяг, носильні речі); англ. togs (одяг), англ. banger (старий автомобіль, рух якого супроводжується шумом, пісня, що стала хітом); 
- стану речей, життєвих обставин: англ. flub (невдача, помилка);

- фізичного стану і властивостей людини, iї організму: англ. wingy (однорука людина);

- емоційного стану людини, його виявів: укр. муфлон (дурна, вперта людина); англ. nut-case (божевільна або дурна людина);

- властивостей особистості, iї поведінки, вчинків: high horse (зверхність у відношенні до оточення), rind (нахабність, самовихваляння), balls (сміливість, хоробрість);

- процесів передачі інформації, актів мовлення, спілкування: укр. ля-ля (пусті розмови); англ. blah (беззмістовна або нещира розмова);

- творів мистецтва: англ. horse opera (фільм у жанрі «вестерн»);

- соціального стану, засад, соціальних відносин: укр. бацька (білоpyc); англ. spaghetti (італієць), укр. мент (міліціонер; будь-який представник правоохоронних органів); англ. cozzpot (поліцейський);

- назви, що оцінюють або характеризують (англ. pippin (щось чудове, неймовірно гарне).

Важливим чинником у творенні сленгових лексем $є$ спорідненість інтересів осіб, які формують різновид цього ненормативного утворення, адже сленг - це мова, зумовлена специфікою діяльності членів відповідної соціальної групи. Сленг є неоднаковим відповідно до спілкування. Кожне з таких середовищ має свої відмінності і сленг озвучує реалії життя саме у цьому оточенні. Отже, за соціальною приналежністю до певної групи людей, зазвичай групи за інтересами або професією, лексичні одиниці сленгу можна поділити, наприклад, на такі, що вживають:

1) у середовищі людей, що мають справу з комп'ютерами: мережі інтернет, програмістів, ігровий сленг;

2) у навчальних закладах: шкільний, студентський сленг;

3) серед тих, хто захоплюється спортом: сленг плавців, танцюристів, футбольних хуліганів;

4) серед воєнних: сленг солдатів, льотчиків;

5) в середовищі людей, пов'язаних із публіцистикою: сленг ЗМI, сленг любителів книг;

6) у колі людей, пов'язаних із законодавством: сленг юристів, політичний сленг;

7) в світі низів суспільства та кримінальному світі: сленг наркоманів, злодіїв, засуджених. 
Отже майже кожна група людей, яких об’єднують спільні інтереси, має свій особливий тип мовлення, який зреалізовано у сленгових новоутвореннях і $€$ притаманним лише цій групі.

\section{4. Переклад рекламного сленгу}

Прагнення до максимальної змістової і структурної близькості перекладу до оригіналу призводить до того, що еквівалентними виявляються не лише тексти, що об'єднуються у процесі перекладу, але й окремі висловлювання в цих текстах, не тільки відповідні висловлювання, а й їхні складові одиниці, як, наприклад, сленгові слова [59]. Переклад сленгізмів найчастіше здійснюється за допомогою еквівалентних відповідників, стилістично нейтральних варіантів чи просторіччя.

Під час перекладу сленгу найприроднішим $\epsilon$ використання еквівалентних відповідників за наявності їх в мові перекладу. Якщо говорити про перекладацьку еквівалентність, то під цим поняттям слід розуміти максимально можливий лінгвістичний ступінь збереження змісту оригіналу в перекладі. Наведемо кілька прикладів перекладу сленгових одиниць за допомогою еквівалентних відповідників:

wild-assed - відморожений; top-поtch - суперовий; dude - чувак; to kill - cтібатися, тюкати; action - тусовка. Еквівалентні відповідники відіграють надзвичайно важливу роль у процесі перекладу. Саме ці лексеми, як перекладацькі одиниці, щонайперше увиразнюються у свідомості перекладача і слугують основою під час виконання перекладу, і вже спираючись на них, перекладач здійснює подальший перекладацький процес.

У деяких випадках за відсутності прямого еквіваленту можна обмежитися стилістично нейтральними варіантами, що передають лише загальне значення сленгової одиниці. Таку функцію пошуку в українській мові достатньо експресивних і образних відтінків сленгізмів виконує сам перекладач. Розглянемо кілька прикладів:

couch potato - лінивий; laid-back - спокійний, врівноважений; to catch some rays - засмагати; fох - приваблива дівчина; guу - друг.

Якщо розглядати трансляцію деяких сленгових одиниць за допомогою стилістично нейтральних варіантів, то потрібно відмітити, що їх переклад не можна визнати достатньо експресивним. Так, наприклад, висловлювання to blow one's top рекомендується перекладати «серди- 
тися», проте і стандартний варіант (to get) very angry також означає «стати дуже сердитим». На українській мові дається ідентичний переклад, а англійською значення абсолютно різні: образна сленгова одиниця (to blow one's top), з однієї сторони, і зворот-стереотип (to get very angry), з іншої [8, с. 84].

Також, якщо відсутні еквівалентні відповідники, можна удатися до просторіччя, яке додає тексту, що перекладається, необхідну характеристику відхилення від літературної норми, наприклад:

longhaired - «інтелігент»; book smart - розумник; assface - дурень; cherry-недоторка; klutz - незграба.

Нерідко перекладач під час трансляції сленгової лексики вдається до низки трансформацій різного характеру. Одним з найефективніших видів перекладацьких трансформацій є варіантні відповідники. Їх використовують тоді, коли одній лексемі мови джерела стаття двомовного словника пропонує кілька варіантів перекладу, і перекладачеві доводиться обирати один 3 них. Варіантні відповідники є множинними, тобто, реалізуються у декількох способах перекладу цієї одиниці мови джерела, причому вибір одного з варіантів продиктовано контекстом [9, с. 243]. Розглянемо низку варіантних відповідників до певних сленгових одиниць:

Досить поширеним видом трансформації у процесі перекладу сленгізмів є заміна частин мови, або конверсія. Нерідко трапляються такі випадки, коли англійські сленгові іменники і прикметники замінюються на українські дієслова. Це в основному стосується іменників з закінченням -er, що широко використовують не лише для означення осіб певної професії, а й взагалі, для означення діяча.

Значення таких іменників, як правило, передають українським дієсловом [8, с. 136]. Наприклад, сленговий іменник arm-twister означає «someone who uses strong persuasion», проте українською мовою значення цього слова передають як «напосідати». Розглянемо цей приклад в реченні:

"I hate to seem like an arm twister, but I really need your help on this project». - Я не хотів би на тебе напосісти, проте мені дійсно потрібна допомога з цим проектом.

Іншим прикладом в цьому контексті слугує сленгове слово eyepopper, що означає «something astonishing»; в українській мові цей 
сленгізм звучить «приголомшливий». Наведемо приклад вживання його в реченні:

Wow, that guy is truly an eyepopper! He is so cute! - Цей хлопець виглядає приголомшливо! Він такий симпатичний!

Нерідко під час перекладу сленгізмів використовують й антонімічний переклад. Це типовий приклад комплексної лексико-граматичної трансформації, у якій одночасно здійснюються модифікації лексичної та синтаксичної структур. Антонімічний переклад спирається на логічний постулат, згідно з яким заперечення будь-якого значення можна прирівняти до ствердження протилежного йому значення.

Цьому відповідає формально-логічна категорія контрадикторності: А не $\epsilon$ не-А або Не-А не $\epsilon$ А [13].

На практиці антонімічний переклад, як правило, пов'язується з заміною однієї з лексем оригіналу на їі міжмовний антонім. Стверджувальна конструкція почасти у реченні вихідного тексту замінюється на заперечну в перекладі і навпаки.

Hold it! - Не рухайся!

I am not kidding! - Я серйозно говорю!

Наявні і випадки перекладу сленгу за допомогою методу цілісного перетворення. Цей метод змінює внутрішню форму будь-якого відрізка мовленнєвого потоку, хоч загальний зміст залишається незмінним. Ступінь змістової спільності між перекладом та оригіналом залишається невисоким і визначається метою комунікації або ідентифікацією ситуації. Розглянемо такі приклади:

Never mind. - Нічого, не зважай. Get away! - Хто б міг подумати?!

No way! - Нізащо! Give it a rest! - Замовкни!

Під час перекладу сленгових одиниць, що не мають безпосередніх відповідностей, перекладач може вдатися до описового перекладу. Недоліком описового перекладу є його громіздкість і багатослівність, тому вдало цей спосіб перекладу застосовується в тих випадках, коли можна обійтися порівняно коротким поясненням:

ball-breaker - жінка, яка демонструє свою владу, принижуючи гідність чоловіків;

goldbrick - людина, та, що ухиляється від виконання своїх обов'язків;

jollop - міцний алкогольний напій. 
Отже, найважливішою метою перекладача під час перекладу сленгізмів $є$ збереження та правильна передача емоційно-експресивного забарвлення та стилістичного відтінку.

Основне завдання перекладача - майстерно виконати різноманітні перекладацькі трансформації для того, щоб текст перекладу якомога точніше передавав всю інформацію, що містить текст оригіналу, дотримуючись відповідних норм мови перекладу. Збереження незмінних стилістичних особливостей початкового тексту, незалежно від його жанрової приналежності, $є$ одним з найголовніших завдань будь-якого перекладу.

Найважливішою метою перекладача під час перекладу сленгізмів $\epsilon$ збереження та правильна передача емоційно-експресивного забарвлення та стилістичного відтінку повідомлення. Інді досягнення цієї мети неможливе, наприклад, якщо перекладач необізнаний з відповідним шаром лексики. Для того, аби виправити цей недолік, фахівці мають ретельно досліджувати і вивчати сленгову лексику. Найлегше це зробити вивчаючи соціальний прошарку населення, який послуговується такою лексикою, аналізуючи реалії життя людей та спілкування 3 ними. Лише так можна досягти найвищого рівня точності і правильності перекладу, що буде переконувати реципієнта у реальності повідомлення, яке він отримує.

Переклад сленгу спонукає використовувати еквівалентні відповідники за їх наявності в мові перекладу. Якщо говорити про перекладацьку еквівалентність, то під цим поняттям слід розуміти максимально можливий лінгвістичний ступінь збереження змісту оригіналу в перекладі.

\section{5. Висновки}

Межі сленгу не $є$ чіткими, тому одні й ті самі слова в різних словниках можуть мати різне значення і бути диференційовані по-різному. Розмитість обсягу цього поняття також зумовлена мовною та соціальною варіативністю в хронологічному плані. Стрімкий суспільний розвиток неминуче призводить до змін у ставленні соціуму до сленгу і його носіїв, прийняття нових ціннісних орієнтирів і норм. Ці процеси зазнають інтенсифікації в умовах постійного розвитку інформаційних технологій та збільшення швидкості, з якою передають інформацію, наближення точки сингулярності в науково-технічному прогресі i обов'язково знаходять відбиття в мові в цілому і сленгу зокрема. 
У рекламних текстах сленг і жаргон є широко поширеними мовними явищами, які дають змогу рекламодавцям впливати на цільову аудиторію для спонукання іiі до певних, заздалегідь задуманих дій. Проте основний акцент зроблено на асоціативне мислення реципієнта і його внутрішні бажання, до яких і апелюють рекламодавці. Отже, рекламний текст і його стилістичне наповнення (сленгізми і жаргонізми) сприяють створенню прагматичного і комунікативного повідомлення, спрямованого на прихований вплив на цільову аудиторію за допомогою звернення до іiі бажання і уподобання. Виявлено, що ступінь впливу сленгізмів та жаргонізмів підвищено завдяки їх використанню в складі певних стилістичних засобів, таких як метафори, повтори, порівняння і епітети, що характеризуються високим ступенем виразності і експресивності.

Задля перекладу рекламних повідомлень потрібно не лише відтворювати висловлення згідно із законами природної мови, а й дотримуватися умов створення рекламних повідомлень. Цю проблему можна визначити як власне перекладацьку проблему еквівалентності рекламного тексту. Переклад рекламних слоганів 3 англійської мови українською має відбуватися з урахуванням таких аспектів, як лінгвокультурний, прагматичний та перекладацький. 3 охопленням усіх проблемних аспектів процес перекладу рекламних слоганів здійснюється відповідно до правил рекламної комунікації, а перекладені слогани функціонують в новому масово-інформаційному просторі як нові комунікативні одиниці.

Під час перекладу сленгу в основному потрібно дотримуватись двох напрямків, зокрема, пошуку аналогічного відповідника, схожого за експресивністю, або через підбір найближчого за емоційним забарвленням відповідника 3 розмовного шару мови. Велику значущість відіграють «фонові знання» про сленг, тобто інформація про ситуацію використання відповідного сленгізму. Цю інформацію, на жаль, мало відбито в сучасних двомовних словниках. Все це певною мірою ускладнює роботу професійних перекладачів і призводить до помилок під час перекладу сленгових одиниць.

Вважаємо, що проблема перекладу сленгу 3 англійської мови на українську недостатньо досліджена і може стати основою подальших досліджень в галузі перекладу. 


\section{Список літератури:}

1. Ахманова О. С. (1969). Словарь лингвистических терминов. Москва: 608.

2. Береговская Э. М. (1996). Молодежный сленг: формирование и функционирование. Вопросы языкознания. № 3: 32-41.

3. Бернет Дж. (2003). Реклама: принципы и практика. Москва: 520.

4. Васильева Л. А. (2004). Реклама и пропаганда в социальной системе информационно-коммуникативного пространства. Вісник ХНУ ім. B. H. Каразіна. Наука. Культура. Постмодерн. № 618: 77-81.

5. Городенська К. (2012). Нові явища та процеси в українському словотворенні: динаміка чи деструкція словотвірних норм? Науковий вісник Чернівецьккого національного університету. Слов'янська філологія. № 648: $180-185$.

6. Грабовий П. М. (2008). Молодіжний сленг у системі соціолектів сучасної української мови. Лінгвістичні студіï. № 16: 294-297.

7. Добланович С. Э. (2013). Особенности реализации коммуникативно-прагматической функции сленгизмов в речи политиков: гендерный подход. Филология. № 3: 249-261.

8. Комиссаров В. Н. (1960). Пособие по переводу с английского языка на русский. Часть I: Лексико-фразеологические основы перевода. Москва : Изд-во Литературы на иностранных языках: 175.

9. Корунець I. В. (2001). Теорія і практика перекладу (аспектний переклад). Вінниця : Нова Книга: 450.

10. Николів I. Н. (2010). Сленг та суміжні з ним поняття з погляду хорватських та українських лінгвістів. Лінгвістичні студї. № 21: 233-237.

11. Пономарів О. Д. (1999). Культура слова: мовностилістичні поради. Київ : Либідь: 240.

12. Русанівський В. М., Тараненко О. О. (2007). Українська мова. Енциклопедія. Київ : «Укр. енцикл». ім. М. П. Бажана: 820.

13. Словник UA. Портал української мови та культури. URL: https://www.slovnyk.ua/

14. Ставицька Л. О. (2005). Арго, жаргон, сленг. Київ : Критика: 464.

15. Шалова Е.С., Привалова Ю.В. (2013). Языковые особенности английских рекламных слоганов и их перевод на русский язык. IX Международная научно-практическая Интернет-конференция "Наука в информаиионном пространстве» (Россия, Ростов-на-Дону, 10-11 октября 2013 г.). URL: http:/www.confcontact.com/2013-nauka-v-informatsionnom-prostranstve/ fl7 shalova.htm

16. Швейцер А. Д. (1983). Социальная дифференциация английского языка в США. Москва : Наука: 216.

17. Ярцева В. Н. (1990). Лингвистический энциклопедический словарь. Москва : Советская энциклопедия: 685.

18. Eble C. (1996). Slang and Sociability: In-Group Language among College Students. Chapel Hill : University of North Carolina Press: 240.

19. Partridge E. (1971). Slang today and yesterday. London, Routledge: 488.

20. Urban Dictionary. URL: http://www.urbandictionary.com/ 


\section{References:}

1. Akhmanova O. S. (1969). Slovar' lingvisticheskikh terminov [Dictionary of linguistic terms]. Moscow: Sovetskaya Entsiklopediya: 608. (in Russian)

2. Beregovskaya E. M. (1996). Molodezhnyy sleng: formirovanie i funktsionirovanie [Youth slang: forming and functioning]. Voprosu jazukoznanija, vol. 3: $32-41$.

3. Bernet Dzh. (2003). Reklama: printsipy i praktika [Advertisement: principles and practice]. Moscow: Piter: 520. (in Russian)

4. Vasil'eva L. A. (2004). Reklama i propaganda v sotsial'noy sisteme informatsionno-kommunikativnogo prostranstva [An advertisement and propaganda in the frame of society of informatively-communicative space]. Visnik KhNU im. V. N. Karazina. Nauka. Kul'tura. Postmodern, vol. 618: 77-81.

5. Horodenska K. (2012). Novi yavyshcha ta protsesy v ukrainskomu slovotvorenni: dynamika chy destruktsiia slovotvirnykh norm? [New phenomena and processes in the Ukrainian word-formation: dynamics or destruction of word-formation norms?]. Naukovyj visnyk Chernivecjkogho nacionaljnogho universytetu. Slov'jansjka filologhija, vol. 648: 180-185. Retrieved from: http://nbuv.gov.ua/ UJRN/Nvchnusf_2012_648-649_30 (accessed 10 February 2021).

6. Hrabovyi P. M. (2008). Molodizhnyi slenh u systemi sotsiolektiv suchasnoi ukrainskoi movy [A youth slang is in the system of social group of modern Ukrainian]. Linghvistychni studiji, vol. 16: 294-297.

7. Doblanovich S. E. (2013). Osobennosti realizatsii kommunikativno-pragmaticheskoy funktsii slengizmov $\mathrm{v}$ rechi politikov: gendernyy podkhod [Features of realization of communicative-pragmatic function of slang in speech of politicians: gender approach]. Filologija, vol. 3: 249-261.

8. Komissarov V. N. (1960). Posobie po perevodu s angliyskogo yazyka na russkiy [Manual on translating from English into Russian]. Moscow: Izd. Literaturu na inostrannuh jazukah: 175. (in Russian)

9. Korunets I. V. (2001). Teoriia i praktyka perekladu (aspektnyi pereklad) [Theory and practice of translation (aspect translation)]. Vinnytsia: Nova Knyha: 450.

10. Nykoliv I. N. (2010). Slenh ta sumizhni z nym poniattia z pohliadu khorvatskykh ta ukrainskykh linhvistiv [Slang and contiguous concepts from the point of view of the Croatian and Ukrainian linguists]. Linhvistychni studii, vol. 21: 233-237.

11. Ponomariv O. D. (1999). Kultura slova: movnostylistychni porady [Culture of word: language and stylistic advice]. Kyiv: Lybid: 240. (in Ukrainian)

12. Rusanivskyi V. M., Taranenko O. O. (2007). Ukrainska mova. Entsyklopediia [Ukrainian language. Encyclopaedia]. Kyiv: Ukr. entsykl. im. M. P. Bazhana: 820.

13. Slovnyk UA. Portal ukrainskoi movy ta kultury: website [Portal of Ukrainian language and culture: website]. Retrieved from: https://www.slovnyk.ua/ (accessed 10 March 2021).

14. Stavytska L. O. (2005). Arho, zharhon, slenh [Argo, jargon, slang]. Kyiv: Krytyka: 464. (in Ukrainian)

15. Shalova E.S., Privalova Yu.V. (2013). Yazykovye osobennosti angliyskikh reklamnykh sloganov i ikh perevod na russkiy yazyk [Language fea- 
tures of the English advertisement slogans and their translation into Russian]. IX Mezhdunarodnaya nauchno-prakticheskaya Internet-konferentsiya "Nauka $v$ informatsionnom prostranstve» (Russia, Rostov-na-Donu, October 10-11, 2013). Retrieved from: http://www.confcontact.com/2013-nauka-v-informatsionnomprostranstve/fl7_shalova.htm

16. Shveytser A. D. (1983). Sotsial'naya differentsiatsiya angliyskogo yazyka $v$ SShA [Social differentiation of English is in the USA]. Moscow: Nauka: 216. (in Russian)

17. Yartseva V. N. (1990). Lingvisticheskiy entsiklopedicheskiy slovar' [Linguistic encyclopaedic dictionary]. Moscow: Sovetskaya entsiklopediya: 685. (in Russian)

18. Eble C. (1996). Slang and Sociability: In-Group Language among College Students. Chapel Hill: University of North Carolina Press: 240.

19. Partridge E. (1971). Slang today and yesterday. London, Routledge: 488.

20. Urban Dictionary: website. Retrieved from: http://www.urbandictionary.com/ (accessed 13 February 2021). 